\title{
Review: Ewa Mazierska, Poland Daily: Economy, Work, Consumption and Social Class in Polish Cinema
}

\section{Eliza Rose}

https://doi.org/10.15664/fcj.v0i17.2058

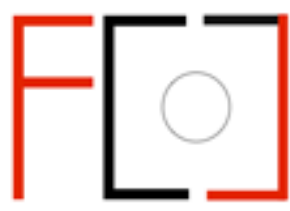

Frames Cinema Journal

ISSN 2053-8812

Issue 17 (Jun 2020)

(c) (†)

http://www.framescinemajournal.com 


\section{Poland Daily: Economy, Work, Consumption and Social Class in Polish Cinema Ewa Mazierska \\ Berghahn Books, 2017 \\ Reviewed by Eliza Rose, University of North Carolina - Chapel Hill}

Using Marxist tools of analysis in the study of socialist Poland can be a freighted choice in today's academy. Ewa Mazierska does precisely this by centring work and class in her sweeping chronicle of Polish cinema. With the book Poland Daily: Economy, Work, Consumption and Social Class in Polish Cinema, Mazierska confronts her field's aversion to analytical language even mildly scented with Marxian notes. Her frankness is a refreshing response to the avoidance of class-based analysis in Polish criticism, Slavic studies, and, by her argument, the broader humanities. Distrust of class as an analytical category reflects a global drift in academic thought that is compounded by factors specific to Poland, where class discourse inevitably conjures personal feelings about the socialist past and the changes following the collapse of the people's democracies. Mazierska traces this wariness after (and in reaction to) class's primacy in critical discourse in the 1960s-70s (1-5), citing Ellen Meiksins Wood on the academy's "retreat from class" and "fastidious middle-class distaste" or even "fear of the working class." This language captures a certain stiffness or discomfort that the academic elite still manifests toward class difference, despite its frequently avowed commitment to "radicality" (an ever exploitable keyword). At bottom, the avoidance of class categories is less an analytical position than it is an attitude, and one that is often unconscious.

Unconscious attitudes are peculiarly resistant to argument, so Mazierska must solidly defend her methodology as a Marxist-oriented film historian before turning her attention to individual films. The book's greatest asset may therefore be its introduction, which reads as a persuasive and portable justification for class-based cultural analysis with potential applications in adjacent areas of literary and area studies. While the critical humanities hungers for viable alternatives to capitalism, the Slavic field's "retreat from class" embargos the region's reservoir of cultural precedents and social models that might answer this very hunger. What lessons about resource sharing, housing solutions, labor management and wealth distribution might be culled from the twentieth century's seven-decade experiment in reorganizing society? Tonally, Mazierska's introduction is a rallying cry: let us scrutinise our own blind spots and bring the study of East European state socialism into the broader project of critiquing global capitalism.

Mazierska's approach is inspired by Henri Lefebvre's embrace of the everyday as a kind of "fertile humus" (her poetic formulation) and "source of life-enhancing power as we walk over it unnoticed" (4). Her project contributes to a body of scholarship devoted to the everyday socialist experience by scholars like Susan Reid, David Crowley and others (the latest effort in this vein is The Socialist Good Life: Desire, Development, and Standards of Living in Eastern Europe, ed. Cristofer Scarboro, Diana Mincyte and Zsuzsa Gille, Indiana University Press, 2020). Rather that rehash postmortems of the socialist system, these scholars emphasise consumption and pleasure over scarcity and deprivation. If Poland Daily contributes something new to research on the socialist everyday, it is perhaps by treating films as legitimate "historical documents" (15). Films become artifacts encoded with the class relations of their moment of production. Fabula, in particular, is a legible transcript of the ways in which the everyday was reconfigured under socialism. 
What does this method look like in practice? Political and economic context constitute 30\% of Poland Daily - a ratio tallied and announced by the author herself. This ratio has interesting effects on the reading experience. The author cleanly segregates context from content, opening each decadebased chapter with an overview of its milestones dispensed at a fast clip. If these opening pages were to be excerpted into a standalone text, they might constitute a decent history crash course for students working on Poland in any discipline. By devoting one chapter to each decade, Mazierska eschews the canonical periodisation and its fixation on boldface years (unrest in 1968; martial law in 1981; the 1989 elections). Her evenly paced chronology honours the intervals between these watersheds.

In the meat of each chapter, the prose transforms. With painstaking breadth, Mazierska supplies plot synopses of her case studies. This format may test the patience of anyone attempting a cover-to-cover read. Students and scholars alike may have limited attention spans for synopses of films they have not seen. On the other hand, the sheer number of relevant films proves Mazierska's thesis that class relations are constitutive of cultural output even beyond the extended event of real existing socialism. Once one begins to see the world through the optics of class, one sees little else. A reader immersed in the body chapters of Poland Daily might forget it is not simply a holistic overview of Polish cinema: does any film fall outside the purview of class analysis?

Part 1 covers the interwar period, which witnessed the birth and consolidation of a film industry native to Poland and the cultivation of a mass audience base. Mazierska notes the formulaic nature of films popular in these years but remains invested in them as objects of analysis. For her, schematic films are records of their historical moment's dominant ideology, which has a way of "speak[ing] through silences" (36). Mazierska maps how financial premises and industry infrastructure determined the content and form of films produced in these years. For example, films had to make back their costs through ticket revenue, hence the boom of genre films (melodramas and comedies) prized for their immediate visceral effects on the audience. The pressure to maintain viewer intelligibility, meanwhile, disincentivised opaque intellectual substance and esoteric style.

Postwar film, we learn in Part 2, was no clean break from the interwar commercial model. Since films needed mass appeal to disseminate Party values, the profit motive was effectively replaced with the Party motive (106). This section covers the socialist period and the film industry's nationalisation. Mazierska is judicious in her assessment of the benefits and drawbacks of state sponsorship of the arts. Her take on social transformation during socialism is equally unbiased: while she concedes lags between doctrine and experience, she also identifies localised successes of socialist planning, such as the Three-Year Plan (1947-49). She contributes to a counter-narrative gaining credence in the Slavic field that resists the neoliberal consensus that socialism was a failure.

Mazierska traces subtle shifts in the cinematic representation of work and industry, from socialist realist "production films" (produkcyjniaki) preceding the Thaw to the "industrial sublime" of the Polish New Wave. A highlight of the book is her reading of three films representative of the latter movement (Jerzy Skolimowski’s Walkover - 1965; Wojciech Solarz's The Pier - 1969, and Wojciech Has' Gold -1962) and their hybridisation of socialist realist settings and a surrealist idiom. She suggests that for these filmmakers, surrealism was not a repudiation of socialist realism, but an alternative or even superior kind of realism. 
The book's final section (Part 3), covering post-socialist cinema, opens with the argument that neoliberalism is as much of a ruling ideology as state socialism. The myth of 1989 as an emancipatory break is discarded at the section's outset. Film in the decade that follows documents the rising middle class whose ascent came at the expense of the working class once lionised by socialism (259). This process was material and symbolic: while whole towns built around single industries fell into decline, working-class experience was symbolically devalued as neoliberal discourse rendered the skills and knowledge of industrial workers irrelevant to the new world. While commercial film studios replaced the former system's state-affiliated Film Units, a government-appointed Committee of Cinema continues to oversee state subsidies to film production, leaving cinema reliant on election cycles and political agendas. Citing this and other symmetries, Mazierska shows how funding structures curbed creative freedom both before and after 1989.

Mazierska's quest for comprehensive coverage may be at the expense of her capacity to elaborate on certain insights. In her analysis of Stanisław Bareja's Marriage of Convenience (1966), for instance, she observes how the distinct temporalities of different classes and professional sectors come together in films, which become vessels for unsynchronised worlds (170). Elsewhere, she makes the compelling argument that postwar documentaries, despite their surface-level reverence for the ordinary worker, robbed workers of their voices by leaning heavily on off-screen commentaries (127). She also begins the work of mapping labour and production as migrating motifs in Polish, Czech and Yugoslav cinema. These 300-odd pages are studded with bait for closer readings.

Perhaps most productively, Poland Daily challenges the popular consensus that socialist realism was a fallow and corrupt aesthetic project. Mazierska pushes against the misconception that popular film is subsumed by hegemonic values while art house film is somehow immune. Many of her case studies have ambiguous orientations to dominant ideology, "pick[ing] and mix[ing] elements from different ideologies" and combining diverse discursive codes. For Mazierska, socialist censorship was a porous form of control (21). For too long, censorship and defiance thereof have been our default categories for interactions between artists and the socialist state. These categories fail to capture the complex configurations of state oversight in People's Poland. Poland Daily sets the agenda for what will surely be the slow and arduous labour of recovering the rich and understudied corpus that is Polish popular cinema.

\footnotetext{
${ }^{1}$ Ellen Meiksins Wood, The Retreat from Class: A New 'True' Socialism (London: Verso, 1986), 3-24, 10-11.

2 This term is borrowed from Industrial Sublime: Modernism and the Transformation of New York's Rivers, 1900-1940, ed. Kirsten Jensen and Bartholomew Bland (New York: Fordham University Press, 2013).
} 